\title{
OCCURRENCE OF TRUE SPIDERS ASSOCIATED WITH CITRUS, APPLE, AND GRAPE FRUIT ORCHARDS AT ALEXANDRIA GOVERNORATE IN EGYPT
}

\author{
Amal E. Abo-Zaed and A. M. Mansour \\ Plant Protection Research Institute, Agricultural Research Center, Dokki, Giza, Egypt \\ Received: Mar. 28 , 2019 \\ Accepted: May. 21, 2019
}

ABSTRACT: This study was carried out to determine the frequency of occurrence and the presence of true spiders associated with citrus, apple and grapefruit trees. This study was conducted at AL-Amriya district in Alexandria Governorate along two successive years 2013-2014. A total of 746 and 797 spiders of 25 species, 22 genera and 11 families were collected in 2013 and 2014, respectively from citrus, apple and grapefruit trees. The most dominant families with the largest number of species were: Salticidae and Theridiidae. While, the families: Agelenidae, Dictynidae, Gnaphosidae, Lycosidae, Miturgidae, Oonopidae, Philodromidae and Thomisidae including few species.

Key words: Araneida, fruit trees, incidence, true spiders, identification, biological control.

\section{INTRODUCTION}

Spiders are one of the more diverse arthropod taxa, ranking seventh in global diversity, which makes them a fascinating group to study (Coddington and Levi, 1991). True spiders are worldwide distributed and occupy many ecological environments through agroecosystems. Taxonomists documented about 117 families, 4128 genera and 48086 species (World Spider Catalog, 2019).

True spiders are one of the most abundance predatory groups in terrestrial ecosystems. The importance of the community of the true spiders as a mortality factor, that they capture a greater number of prey species than they consume (Nyffeler et al., 1992). Spiders have proved to be beneficial in regulation of agricultural pests and their role as natural enemies has recently been more and more stressed (Ghabbour et al., 1999). They occur with considerable densities in agro-ecosystems in the old land of the Delta and Middle Egypt (Ghabbour and Mikhail, 1993).
Ecological parameters and taxonomic importance of different species of spiders from fruit gardens, cotton fields, citrus and guava fruit gardens were investigated by many researchers (EIHennawy, 1992; Sallam, 1996; Mohafez, 2004; Alvi, 2007; Maqsood, 2011).

This article aimed to explore the importance of the true spiders on citrus, apple and grape trees at AL-Amriya district in Alexandria Governorate.

\section{MATERIALS AND METHODS}

Individuals of the true spiders were randomly collected from citrus, apple and grape fruit trees and bushes included branches, leaves and trunks along two seasons 2013-2014 at AL-Amriya provinces in Alexandria Governorate. The samples were collected biweekly during two hours from 9-11 am during summer and 10-12 am in winter on fine silky traps. True spiders were collected from branches, leaves and trunks of different trees and bushes, by shaking five to six branches in their length between 100 to $150 \mathrm{~cm}$ from the four directions of a tree for each sample. The spiders were 
isolated and counted in glasses and transferred in the same day to the laboratory at the Plant Protection Research Institute for counting and identification. The collected spiders were kept individually in small test tubes containing $70 \%$ ethyl alcohol. The necessary information (locality, host plant, date) was recorded by a pencil on a slip of paper attached to each specimen inside the tube for identification. The characteristics of families, genera and species were examined using the related keys. The samples were collected during two successive years (2013 and 2014) depending on the host plant (citrus from Jan. to Dec. but apple and grape from March. to Oct.).

The different spider families and species (members were counted) during all the investigation periods and classifies as mentioned before.

Identification of specimens was conducted with the aid of the descriptions of (Petrunkevitch, 1939; Kaston, 1978; Jocque and DippenaarSchoeman, 2007). Final identification was conducted by Mr. H. K. El-Hennawy, Characteristics of obtained families, genera and species were presented. In some cases, identification was possible only to the genus level.

Frequency of occurrence (F.O.) \% = $\frac{\text { No of sample containing a species }}{\text { No of collected sample }}$ X100

Population fluctuation $=$ No. of individual of a species

No of sample contaning this species

\section{RESULTS AND DISCUSSION}

Distribution and occurrence of true spiders associated with some fruit orchards (citrus, apple and grape) in AlAmiriyah location of Alexandria Governorate, was determined and presented in Tables $(1,2,3)$.

\section{1- Citrus plantations}

The obtained data in Table (1) revealed that the collected spiders were 16 spider species belonging to 15 genera under 9 different families. The families as shown in Table (1) were Agelenidae, Dictynidae, Gnaphosidae, Lycosidae, Miturgidae, Oecobiidae, Philodromidae, Salticidae and Theridiidae. The highest abundant families in this study were observed for families, Salticidae and Theridiidae, as each of them harbored seven different species in them. The citrus plants harbored more abundant spiders during the second season 2014 more than the first season 2013, it record 284 and 312 individuals, respectively.

The salticid spiders on citrus trees were Ballus piger, Euophrys sp., and Plexippus sp., while theridiid spider species in this study associated with citrus plants were Kochiura aulica, Enoplognatha deserta, Steatoda sp. and Theridion melanostictum.

As shown in Table (1) the frequency of occurrence of the collected families, Dictynidae, Gnaphosidae, Lycosidae, Miturgidae, Oecobiidae, Philodromidae, Salticidae and Theridiidae during 2013 season on citrus plants were 58.33, $83.33,100,100,100,100,100$ and $100 \%$ on citrus. On the other hand, the frequency of occurrence of Agelenidae, Dictynidae, Gnaphosidae, Lycosidae, Miturgidae, Philodromidae, Salticidae and Theridiidae on the same plantations were $33.33,100,100,100,100,100,100,100$ and $100 \%$ during season 2014, respectively.

The highest number of spider individuals was recorded in the family Dictynidae (61 individuals) with $58.33 \%$ of frequency, while the frequency of occurrence of spiders on Oecobiidae (20 individuals) was 100 during 2013 season; whereas during 2014 season the members of family Theridiidae was recorded the highest number (57 
Occurrence of true spiders associated with citrus, apple, and grape fruit .....

individuals) and the lowest number individuals, with 100 and $33.33 \%$ recorded of family Agelenidae was 17 frequency, respectively.

Table (1). Occurrence and frequencies of spider families associated with citrus during 2013 - 2014 season at AL-Amriya in Alexandria Governorate

\begin{tabular}{|c|c|c|c|c|c|c|c|c|}
\hline \multirow[b]{2}{*}{ Families and species } & \multicolumn{4}{|c|}{2013} & \multicolumn{4}{|c|}{2014} \\
\hline & T.s. & T.N. & P.D. & $\begin{array}{l}\text { F.O. } \\
\%\end{array}$ & T.s. & T.N. & P.D. & $\begin{array}{c}\text { F.O. } \\
\%\end{array}$ \\
\hline Agelenidae (Koch) & - & - & - & - & 17 & 4 & 4.25 & 33.3 \\
\hline Tgenaria sp. & - & - & - & - & 17 & 4 & 4.25 & 33.3 \\
\hline Dictynidae Cambridge) & 61 & 7 & 8.71 & 58.3 & 53 & 12 & 4.42 & 100 \\
\hline Dictyna sp. & 61 & 7 & 8.71 & 58.3 & 53 & 12 & 4.42 & 100 \\
\hline Gnaphosidae (Pocock 1984) & 23 & 10 & 2.3 & 83.3 & 35 & 12 & 2.92 & 100 \\
\hline Poecilochroa sp. & - & - & - & - & 35 & 12 & 2.92 & 100 \\
\hline Zelotes sp. & 23 & 10 & 2.3 & 83.3 & - & - & - & - \\
\hline Lycosidae (Sundevall) & 31 & 12 & 1.55 & 100 & 29 & 12 & 4.20 & 100 \\
\hline Pardosa serena (kock) & - & - & - & - & 29 & 12 & 4.20 & 100 \\
\hline Pardosa sp. & 31 & 12 & 1.55 & 100 & - & - & - & - \\
\hline Miturgidae (Wager) & 29 & 12 & 2.42 & 100 & 46 & 12 & 3.83 & 100 \\
\hline $\begin{array}{l}\text { Cheiracanthium isiacum } \\
\text { (Cambridge) }\end{array}$ & 29 & 12 & 2.42 & 100 & 46 & 12 & 3.83 & 100 \\
\hline Oecobiidae (Blackwall) & 20 & 12 & 1.67 & 100 & - & - & - & - \\
\hline Oecobius sp. & 20 & 12 & 1.67 & 100 & - & - & - & - \\
\hline Philodromidae (Thorell) & 23 & 12 & 1.92 & 100 & 25 & 12 & 2.68 & 100 \\
\hline Thanatus albini (Audouin) & 23 & 12 & 1.92 & 100 & 25 & 12 & 2.68 & 100 \\
\hline Salticidae (Blackwall) & 44 & 12 & 3.66 & 100 & 50 & 12 & 4.17 & 100 \\
\hline $\begin{array}{c}\text { Ballus piger } \\
\text { (O.P.Cambridge) }\end{array}$ & 12 & 10 & 1.20 & 83.3 & - & - & - & - \\
\hline Euophrys sp. & 22 & 12 & 1.83 & 100 & 50 & 12 & 4.17 & 100 \\
\hline Plexippus sp. & 10 & 9 & 1.11 & 75 & - & - & - & - \\
\hline Theridiidae (Sundevall) & 50 & 12 & 4.17 & 100 & 57 & 12 & 4.75 & 100 \\
\hline Kochiura aulica (kock) & 10 & 9 & 1.11 & 75 & - & - & - & - \\
\hline $\begin{array}{l}\text { Enoplognatha deserta } \\
\text { Levy\& Amitai }\end{array}$ & - & - & - & - & 7 & 5 & 1.4 & 41.6 \\
\hline Steatoda sp. Levy\& Amitai & 16 & 10 & 1.6 & 83.3 & 25 & 12 & 2.08 & 100 \\
\hline Theridion melanostictum & 24 & 12 & 2 & 100 & 25 & 10 & 2.5 & 83.3 \\
\hline Total number & 281 & 89 & - & - & 312 & 88 & - & - \\
\hline
\end{tabular}

T.s. : Total individuals of species; T. N.: Total No. of samples containing species;

P.D.: Population density; F.O. \%: Frequency of occurrence. 
Amal E. Abo-Zaed and A. M. Mansour

Table (2). Occurrence and frequencies of spider families associated with apple during 2013 -2014 season at Al-amriya in Alexandria Governorate

\begin{tabular}{|c|c|c|c|c|c|c|c|c|}
\hline \multirow[b]{2}{*}{ Families and species } & \multicolumn{4}{|c|}{2013} & \multicolumn{4}{|c|}{2014} \\
\hline & T.s. & T.N. & P.D. & $\begin{array}{c}\text { F.O. } \\
\%\end{array}$ & T.s. & T.N. & P.D. & $\begin{array}{c}\text { F.O. } \\
\%\end{array}$ \\
\hline Agelenidae (Koch) & 6 & 2 & 3.0 & 25.0 & 12 & 7 & 1.71 & 87.5 \\
\hline Tgenaria sp. & 6 & 2 & 3.0 & 25.0 & 12 & 7 & 1.71 & 87.5 \\
\hline Dictynidae Cambridge) & 20 & 4 & 5.0 & 50.0 & 17 & 7 & 2.43 & 87.5 \\
\hline Dictyna sp. & 20 & 4 & 5 & 50.0 & 17 & 7 & 2.43 & 87.5 \\
\hline Gnaphosidae (Pocock 1984) & 23 & 8 & 2.88 & 100 & 17 & 8 & 2.13 & 100 \\
\hline $\begin{array}{l}\text { Drossades muscorum } \\
\text { (O.P.Cambridge) }\end{array}$ & 23 & 8 & 2.88 & 100 & 7 & 5 & 1.4 & 62.5 \\
\hline Zelotes sp. & - & - & - & - & 10 & 8 & 1.25 & 100 \\
\hline Lycosidae (Sundevall) & 9 & 5 & 1.8 & 62.5 & 8 & 6 & 1.33 & 75.0 \\
\hline Pardosa serena (kock) & 4 & 3 & 1.33 & 37.5 & - & - & - & - \\
\hline Pardosa sp. & 2 & 2 & 1 & 25 & 6 & 5 & 1.2 & 62.5 \\
\hline $\begin{array}{l}\text { Pirata proximus } \\
\text { (O.P.Cambridge) }\end{array}$ & 3 & 3 & 1 & 37.5 & 2 & 2 & 1 & 25 \\
\hline Miturgidae (Wager) & 7 & 2 & 3.5 & 25 & 7 & 3 & 2.33 & 37.5 \\
\hline $\begin{array}{l}\text { Cheiracanthium isiacum } \\
\text { (Cambridge) }\end{array}$ & 7 & 2 & 3.5 & 25 & 7 & 3 & 2.33 & 37.5 \\
\hline Oonopidae (Simon) & 11 & 4 & 2.75 & 50.0 & 7 & 3 & 2.33 & 37.5 \\
\hline $\begin{array}{l}\text { Dysderina scutata } \\
\text { (O.P.Cambridge) }\end{array}$ & 11 & 4 & 2.75 & 50.0 & 7 & 3 & 2.33 & 37.5 \\
\hline Philodromidae (Thorell) & 13 & 7 & 1.86 & 87.5 & 19 & 6 & 3.17 & 75.0 \\
\hline Philodromus sp. & 7 & 6 & 1.16 & 75 & 11 & 8 & 1.37 & 100 \\
\hline Thanatus albini (Audouin) & 6 & 5 & 1.2 & 62.3 & 8 & 7 & 1.14 & 87.5 \\
\hline Salticidae (Blackwall) & 20 & 8 & 2.50 & 100 & 16 & 5 & 3.2 & 62.5 \\
\hline Ballus pigr (O.P.Cambridge) & 7 & 5 & 1.4 & 62.3 & 5 & 5 & 1 & 62.5 \\
\hline Euophrys sp. & - & - & - & - & 3 & 2 & 1.5 & 25 \\
\hline Plexippus paykulli Audouin & 6 & 6 & 1. & 75 & 4 & 3 & 1.33 & 37.5 \\
\hline Plexippus sp. & 4 & 3 & 1.33 & 37.5 & 3 & 2 & 1.5 & 25 \\
\hline Salticus sp. & 3 & 2 & 1.5 & 25 & 1 & 1 & 1 & 12.5 \\
\hline Theridiidae (Sundevall) & 27 & 8 & 3.38 & 100 & 21 & 8 & 2.63 & 100 \\
\hline Kochiura aulica (kock) & 20 & 8 & 2.5 & 100 & 11 & 8 & 1.37 & 100 \\
\hline $\begin{array}{l}\text { Enoplogna thadeserta } \\
\text { Levy\& Amitai }\end{array}$ & 3 & 3 & 1 & 37.5 & - & - & - & - \\
\hline Steatoda sp & - & - & - & - & 10 & 7 & 1.42 & 87.5 \\
\hline Theridion melanostictum & 4 & 3 & 1.33 & 37.5 & - & - & - & - \\
\hline Thomisidae (Sundevall) & 12 & 5 & 2.4 & 62.5 & 17 & 8 & 2.13 & 100 \\
\hline Misumena sp. & 12 & 5 & 2.4 & 62.5 & - & - & - & - \\
\hline $\begin{array}{l}\text { Thomisus spinifer } \\
\text { O.P.Cambridge }\end{array}$ & - & - & - & - & 17 & 8 & 2.13 & 100 \\
\hline Total number & 137 & 49 & - & - & 134 & 58 & - & - \\
\hline
\end{tabular}

T.s. : Total individuals of species; T. N.: Total No. of samples containing species;

P.D.: Population density; F.O. \%: Frequency of occurrence. 
Occurrence of true spiders associated with citrus, apple, and grape fruit .....

Table (3). Occurrence and frequencies of spider families associated with grape during 2013 -2014 season at Al-amriya in Alexandria Governorate

\begin{tabular}{|l|c|c|c|c|c|c|c|c|}
\hline \multirow{2}{*}{ Families and species } & \multicolumn{3}{|c|}{2013} & \multicolumn{4}{|c|}{2014} \\
\cline { 2 - 9 } & T.s. & T.N. & P.D. & $\begin{array}{c}\text { F.O. } \\
\%\end{array}$ & T.s. & T.N. & P.D. & $\begin{array}{c}\text { F.O. } \\
\%\end{array}$ \\
\hline Agelenidae (Koch) & 43 & 8 & 5.37 & 100 & 64 & 8 & 8.0 & 100 \\
\hline Tgenaria sp. & 43 & 8 & 5.37 & 100 & 64 & 8 & 8.0 & 100 \\
\hline Dictynidae Cambridge) & 31 & 7 & 4.43 & 87.5 & 22 & 8 & 2.75 & 100 \\
\hline Dictyna sp. & 31 & 7 & 4.43 & 87.5 & 22 & 8 & 2.57 & 100 \\
\hline Gnaphosidae (Pocock 1984) & 60 & 8 & 7.50 & 100 & 70 & 8 & 8.75 & 100 \\
\hline Poecilochroa sp. & 32 & 8 & 4 & 100 & 28 & 8 & 3.5 & 100 \\
\hline Zelotes sp. & 28 & 8 & 3.5 & 100 & 42 & 8 & 5.25 & 100 \\
\hline Lycosidae (Sundevall) & 35 & 7 & 5.0 & 87.5 & 20 & 6 & 3.33 & 75.0 \\
\hline Pardosa sp. & 35 & 7 & 5.0 & 87.5 & 20 & 6 & 3.33 & 75.0 \\
\hline Miturgidae (Wager) & 20 & 8 & 2.50 & 100 & 23 & 8 & 2.88 & 100 \\
\hline $\begin{array}{l}\text { Cheiracanthium } \\
\text { isiacum(Cambridge) }\end{array}$ & 20 & 8 & 2.50 & 100 & 23 & 8 & 2.88 & 100 \\
\hline Oecobiidae (Blackwall) & 16 & 6 & 2.67 & 75.0 & 17 & 5 & 3.40 & 62.5 \\
\hline $\begin{array}{l}\text { Oecobius putus } \\
\text { (O.P.Cambridge) }\end{array}$ & 16 & 6 & 2.67 & 75.0 & 17 & 5 & 3.40 & 62.5 \\
\hline Oonopidae (Simon) & 18 & 8 & 2.25 & 100 & 16 & 6 & 2.66 & 75.0 \\
\hline $\begin{array}{l}\text { Dysderina scutata } \\
\text { (O.P.Cambridge) }\end{array}$ & 18 & 8 & 2.25 & 100 & 16 & 6 & 2.66 & 75.0 \\
\hline Philodromidae (Thorell) & 22 & 6 & 3.66 & 75.0 & 37 & 8 & 7.40 & 62.5 \\
\hline Thanatus albini (Audouin) & 22 & 6 & 3.66 & 75.0 & 37 & 8 & 7.40 & 62.5 \\
\hline Salticidae (Blackwall) & 28 & 5 & 5.60 & 62.5 & 27 & 8 & 3.38 & 100 \\
\hline Plexippus paykulli Audouin & 28 & 5 & 5.60 & 62.5 & 20 & 8 & 2.5 & 100 \\
\hline Plexippus sp. & - & - & - & - & 7 & 5 & 1.4 & 62.5 \\
\hline Theridiidae (Sundevall) & 55 & 8 & 6.88 & 100 & 33 & 8 & 4.13 & 100 \\
\hline Kochiura aulica (Kock) & 22 & 8 & 2.75 & 100 & 15 & 8 & 1.87 & 100 \\
\hline Steatoda sp. & 17 & 8 & 2.12 & 100 & - & - & - & - \\
\hline Theridion melanostictum & 16 & 8 & 2 & 100 & 18 & 8 & 2.25 & 100 \\
\hline Thomisidae (Sundevall) & - & - & - & - & 22 & 5 & 4.4 & 62.5 \\
\hline Misumena sp. & - & - & - & 22 & 5 & 4.4 & 62.5 \\
\hline Total number & 71 & - & - & 351 & 78 & - & - \\
\hline
\end{tabular}

T.s. : Total individuals of species; T. N. : Total No. of samples containing species;

P.D. : Population density; F.O. \% : Frequency of occurrence.

\section{2-Apple plantations}

The obtained results in Table (2) proved that the collected spiders were 22 spider species belonging to 20 genera under 10 families. The families were
Agelenidae, Dictynidae, Gnaphosidae, Lycosidae, Miturgidae, Oonopidae, Philodromidae, Salticidae, Theridiidae and Thomisidae. 
The number of collected spiders associated with apple orchard was 137 and 134 individuals during the first and second season, respectively. The dominant spider families and the frequency of occurrence at Al-Ameria region was determined for the members of the spider families Gnaphosidae, Salticidae and Theridiidae and recorded $100 \%$, but the lowest frequency was determined for the families Agelenidae and Miturgidae (25\%).

The highest abundance of the true spiders was recorded for the members of family Theridiidae as it represented by 27 and 21 spider individuals during the first and second season, respectively. Whereas, the lowest population for the family Agelenidae was 6 individuals during 2013 season and for the family Miturgidae was 7 individuals in the second year 2014.

\section{3- Grape plantations}

The obtained results in Table (3) indicated that the collected spiders were 15 spider species belonging to 14 genera under 11 families. The families were Agelenidae, Dictynidae, Gnaphosidae, Lycosidae, Miturgidae, Oecobiidae, Oonopidae, Philodromidae, Salticidae, Theridiidae and Thomisidae. The numbers of spider individuals associated with grape trees were 328 and 351 individuals during the first and second season, respectively.

As for the values of population and frequencies of occurrence of different true spiders during season 2013 of grape plantations, it can be noticed that the highest frequencies were recorded for the members of families Gnaphosidae followed by Theridiidae and Agelenidae represented by 60,55 and 43 spider individuals, respectively, but individuals of family Oecobiidae was recorded the lowest frequencies represented by 18 spider individuals. While, in season 2014 the highest abundance of the collected spider was for the members of family Gnaphosidae (70 individuals), the highest frequency was determined for the members of families: Agelenidae, Dictynidae, Gnaphosidae, Miturgidae, Salticidae and Theridiidae (100\%).

The obtained results are in harmony with that conducted by Ghabbour et al. (1999) who surveyed spiders in 18 different crops in Menoufiya governorate, using pitfall traps, and recorded 10 spider families on winter crops, where Lycosidae was the dominant family constituting about $\mathbf{8 0} \%$ followed by Linyphiidae, Philodromidae, Gnaphosidae and Tetragnathidae.

In addition, similar results were obtained by (El-Hennawy, 1992; Sallam, 1996; Mohafez, 2004; Alvi, 2007; Maqsood, 2011).

\section{REFERENCES}

Alvi, Z. H. (2007). Taxonomical and ecological studies of spiders from some fruit gardens of district Jhang, M. Phil. Thesis (Unpublished), Dept. Zoology, Govt. College Univ., Faisalabad.

Coddington, J. A. and H. Levi (1991). Systematics and evolution of spiders (Araneae). Annual Review of Ecology, Evolution, and Systematics, 22: 565592.

El-Hennawy, H.K. (1992). Distribution of Spider Genera in Egypt (Arachnida: Araneida). Serket 3(1): 1-32.

Ghabbour, S. I. and W. Z. A. Mikhail (1993). Habitat classification using soil fauna populations. Publications of the National Biodiversity Unit No.1, 203236.

Ghabbour, S. I., A. M. Hussein and H. K. El-Hennawy (1999). Spider populations associated with different crops in Menoufiya Governorate, Nile 
Delta, Egypt. Egypt. J. Agric. Res., 77 (3), 1163-1179.

Jocqué, R. and A. S. DippenaarSchoeman (2007). Spiders families of the world. Belgium, Peteers nv, Royal Museum for Central Africa, 336pp.

Kaston, B.J. (1978). How to know the spider. W.C. Brown Co., Dubuque, lowa, U.S.A., 272pp.

Maqsood, I. (2011). Taxonomical and ecological studies of spiders from the citrus and guava fruit gardens of district Faisalabad, Pakistan, M. Phil. Thesis Unpublished, Dept. of Zoology, Govt., College Univ. Faisalabad, Pakistan.

Mohafez, M. A. M. (2004). Ecological and biological studies on spiders in Egypt. Ph.D. Thesis, Fac. Agric. Al-Azhar Univ., 178 pp.
Nyffeler, M., D. A. Dean and W. L. Sterling (1992). Diets, feeding specialization and predatory role of two lynx spiders, Oxyopes salticus and Peucetia viridans (Araneae: Oxyopidae), in a Texas cotton agro ecosystems. Environ. Entomology, (21): 1457-1465.

Petrunkevitch, A. (1939). Catalogue of American spiders. Part one. Transactions of the Connecticut Academy of Arts and Sciences, 33: 133-338.

Sallam, G.M.E. (1996). Studies on true spiders in Giza Governorate. M.Sc. Thesis, Fac. Agric. Cairo Univ., 139pp.

World Spider Catalog. (2019). Natural History Museum Bern, online at http://wsc.nmbe.ch, version 20.0, accessed on [Accessed Feb. 2018]. 


\title{
تواجد العناكب الحقيقية المرتبطة ببساتين الموالح والتفاح والعنب بمحافظة الإسكندرية بمصر
}

\author{
آمال إبراهيم أبوزيلا ، أحمد محمد منصور

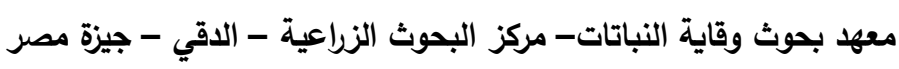

الملخص العربى

تم دراسة تتابع التواجد للعناكب الحقيقية المرتبطة على أشجار الموالح والتفاح والعنب فى منطقة العامرية

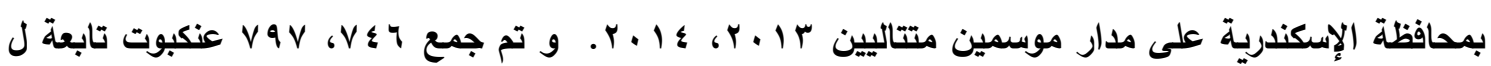

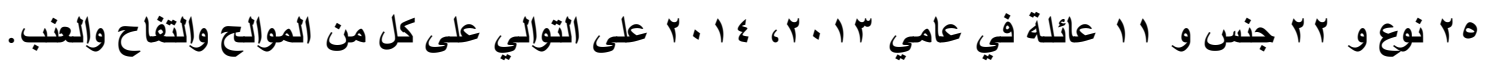

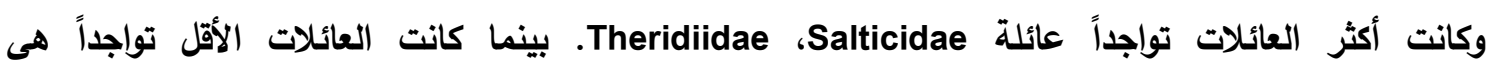

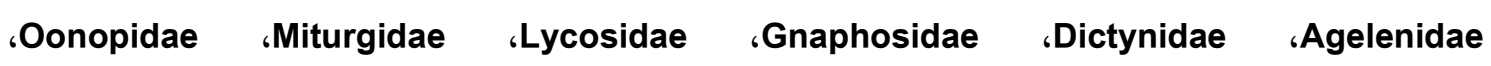
.Thomisidae ،Philodromidae 
Occurrence of true spiders associated with citrus, apple, and grape fruit ..... 